Volume: 7

Issue: 2

Month: March

Year: 2019

ISSN: 2319-961X

Received: 5.3.2019

Accepted: 11.3.2019

Published: 15.3.2019

Citation:

Shamala, B., and T. Rajendra Prasad. "The Socio Economic Status of Unorganised Migrant Construction Labourers in Karnataka: A Case Study in Bangalore." Shanlax International Journal of Economics, vol. 7, no. 2, 2019, pp. 62-67.

DOI:

https://doi.org/10.34293/ economics.v7i2.319

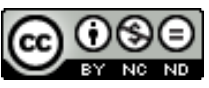

This work is licensed under a Creative Commons Attribution-NonCommercialNoDerivatives 4.0 International License

\section{The Socio Economic Status of Unorganised Migrant Construction Labourers in Karnataka: A Case Study in Bangalore}

\section{B.Shamala}

Research Scholar, Department of Economics

Bangalore University, Bangalore, Karnataka, India

\section{T.Rajendra Prasad}

Professor and Chairman, Department of Economics

Bangalore University, Bangalore, Karnataka, India

\begin{abstract}
Migration is an important feature of development of any economy. It occurs as a response to unbalanced growth and economic inequality. Construction industry is one of the fastest growing industry in the country. The infrastructural development and construction sector is in full swing in Bangalore attracting semi-skilled and unskilled labourers from different parts of the country. While it may seem that construction industry would fetch workers higher income and better working conditions, these unorganized migrant labourers are denied of basic facilities that any citizen of the country is entitled to. This paper tries to study the economic position of labourers before and after migration, their living conditions, food security, health facilities etc., primary data are collected from randomly selected labourers especially interstate migrants and secondary sources of data are collected to analyses the conditions of migrant labourers.
\end{abstract}

Keywords: Migrant labourers, unbalanced growth, Economic inequality, unorganized workers, unskilled workers, semi-skilled workers, agriculture labourers, non-remunerative, Landless laborers, contractors and illiterates.

\section{Introduction}

Migration is a characteristic feature of the growth process of any nation. It occurs as a response to unbalanced growth and economic inequality. Macro level estimates shows that migration for economic reasons has increased in the recent years .According to estimates from the Census, the total number of economic migrants increased from 19.85 million in 1991 to 28.9 million in 2001. Even the NSS estimates show a steady increase in the urban male migration rates from 12.73 percent in 1993 to 14.36 percent in 2007-08 (Srivastava, 2011).

Today the construction industry is a pool of opportunities progressing at a very faster rate. It is the second largest employer after agriculture and can be considered as one of the primary sector in urban areas. The asset creation potential of the construction sector is estimated at 3,50,000 crores. The share to the GDP is $12 \%$ and provides employment to $14 \%$ of employable citizens. It is estimated to create 20.17 million new jobs in the country by the year 2020 . 


\section{Present Study}

The status of migrant labourers in the construction sector have been hardly and empirically studied. But, their economic position, working conditions, housing, food security, health entitlements, education etc. merits a serious study. It is in this context that the present study was conceived to help to answer some of the pertinent questions concerning migrant construction workers in Bangalore city.

\section{Scope of the Study}

The present study involves the migrant workers employed in various construction sites specifically the inter-state migrants are considered .The migrant construction workers only within Bangalore city are selected for the study.

\section{Objectives}

- To compare the economic status of labourers before and after migration.

- To examine the food, health and education entitlements of migrant labourers

- To understand the working conditions of migrant labourers.

- To study the problems faced by the migrant construction workers

- To provide few suggestions for their betterment.

\section{Methodology}

The survey sample method was used to collect data pertaining to inter - state migrant construction labourers. The workers working in construction of apartments, individual houses were considered for survey. A sample of 100 respondents were selected for the study. Secondary data were collected from various published books, articles, journals, central and state government reports, census report and NSSO reports.

\section{Migration in India}

In India the data on Labour migration is collected once in ten years by Census and every year by NSSO, but there is some conceptual differences in defining migration by both. Census defines migrants by place of birth and by a place of last residence. So, a migrant according to the place of birth concept, is one who lives in a place (place of enumeration) that is different than her place of birth. On the other hand, a person is considered migrant by place of last residence if the place of enumeration during census is different than her place of residence. The NSSO in order to find out migrants enquires about usual place of residence. Therefore according to NSSO, a person is a migrant in case he/she stayed for more than six months in a place which is different than her last usual place of residence.

\section{A Profile of Migrants in India by Place of birth (in millions)}

The data on migration from 2011 census is yet to be in the public domain. So, the study has tried to compare the migration of labourers in 1991 and 2001 .

Table 1: Showing the total migrants in India in 1991 and 2001

\begin{tabular}{|l|c|c|c|}
\hline $\begin{array}{c}\text { Migrants } \\
\text { by place of } \\
\text { birth }\end{array}$ & 2001 census & 1991 census & \\
\hline $\begin{array}{l}\text { Total } \\
\text { Population }\end{array}$ & 1028.6 & 838.5 & \\
\hline \multicolumn{4}{|c|}{ Total Migrants } \\
\hline Persons & 307.1 & 229.8 & 1.34 \\
\hline Intra-district & 181.7 & 136.2 & 1.33 \\
\hline Inter - State & 42.3 & 27.2 & 1.56 \\
\hline From Abroad & 6.1 & 6.9 & 0.88 \\
\hline
\end{tabular}

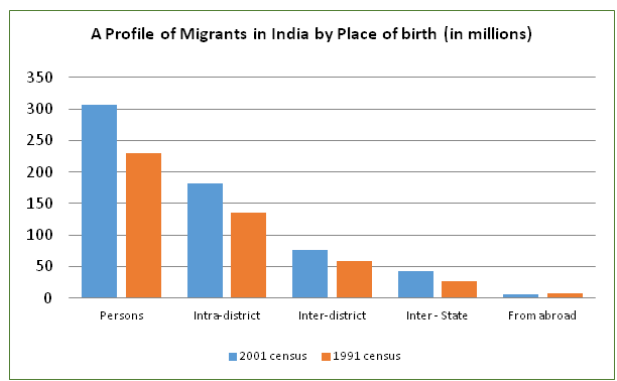

The Socio Economic Status of migrant Construction Labourers in Bangalore

Construction industry provides jobs to many unskilled and semiskilled workers in Bangalore. Karnataka, with its recent industrial and IT related development around Bangalore, a state capital, is an important target for movement from the densely 
populated rural areas of three neighboring states of Kerala, Tamil Nadu and Andhra Pradesh. Migrants from districts like Gulbarga, Raichur i.e. mostly from poorer district with poor employment opportunities, poor landless farmers are migrating towards Bangalore in search of employment opportunities in the faster growing construction sector. Construction industry in Bangalore is unorganized in nature is attracting workers from different parts of the country and state.

In order to compare the economic status of labourers before and after migration, a sample of 100 migrant labourers from within the state working in different apartment and house construction workers were selected randomly, of which few were skilled, semiskilled and some of them were unskilled workers. So, in order to compare the income level of these workers, questionnaire was structured to know their occupation and income before migration and it was compared with the present income level. All the respondents were from North Karnataka i.e., Gulbarga and Raichur. It can be observed that many of the migrants have settled in Bangalore from 1015 years long and have permanently settled with all voting rights, other social entitlements extended by government. We can find Gulbarga colonies built by government by converting slums into wellstructuredpukka houses with all electricity, water and sanitation facilities in many areas in Bangalore.

Table 2: Showing the occupation and income level before and after migration

\begin{tabular}{|l|l|}
\hline \multicolumn{1}{|c|}{ Occupation } & \multicolumn{1}{c|}{ Income } \\
\hline Cattle rearing & Around Rs 30-35 per day \\
\hline Domestic worker & Rs 1000 - 1200 per month \\
\hline Tree climbers & Rs 50 per climbing per tree \\
\hline Farmers & $\begin{array}{l}\text { Rs 100 per day during } \\
\text { harvest season (seasonal } \\
\text { employment) }\end{array}$ \\
\hline $\begin{array}{l}\text { Construction } \\
\text { workers }\end{array}$ & $\begin{array}{l}\text { Rs 100-120 /unskilled, Rs } \\
\text { 200/ semi-skilled, Rs 350/ } \\
\text { skilled }\end{array}$ \\
\hline Others & Rs 55-60 per day \\
\hline
\end{tabular}

After collecting data from the respondents the main jobs in which they were involved was taken into consideration to know their income level at their place of birth. With the available data it could be understood that an unskilled or semiskilled worker earned around Rs 900-1000 per month, and sometimes even lesser if they did not get work for the entire week or month. For example the tree climbers were engaged only when there was need and remained unemployed most of the days. Semiskilled and skilled labourers could earn Rs 30003500 per month if they were working in construction sector. Many workers who reared their own cattle did not earn anything but reported that they had to travel long ways in the hot sun along with cattle in search of water and food.Most of these work were seasonal in nature and non-remunerative which forced them to leave their birth places and migrate towards Bangalore in search of better life most of the times along with the family.

Table 3: Income level after migration in construction industry

\begin{tabular}{|l|c|c|c|}
\hline Skill/Income & $\begin{array}{l}\text { Skilled } \\
\text { labour }\end{array}$ & Semi-skilled & Unskilled \\
\hline $\begin{array}{l}\text { No of } \\
\text { labourers }\end{array}$ & 24 & 41 & 35 \\
\hline $\begin{array}{l}\text { Income } \\
\text { before } \\
\text { migration } \\
\text { (Rs. per day) }\end{array}$ & $250-300$ & $150-180$ & $35-55$ \\
\hline $\begin{array}{l}\text { Income after } \\
\text { migration } \\
\text { (Rs. Per day) }\end{array}$ & $750-900$ & $400-500$ & $200-250$ \\
\hline
\end{tabular}

The above table gives the details of the income level of the migrant workers before and after migration. The table shows that there is an improvement in the economic status of the migrant labour after having started working in construction sector. The workers are satisfied to have found a livelihood. Many of the landless labourers who were working as agricultural labourers couldn't make even two meals a day in their native places and now at least they have two meals a day. Table 2 reveals that the skilled workers like meastris (contractors), painters,granite workers, electricians are earning more than three times of what they were earning before. Semi-skilled workers have almost doubled their earnings after migration. The unskilled workers led a very pathetic life because they earned around rs55 to 75 per day and that too only on the days on which they found job, many a times they didn't find any work and had to lead life with just Rs. 700800/- per month. But after being migrated and found 
work as helpers in the construction site, they are earning a minimum of Rs 250/- per day. So, the table reveals that the economic position of the workers has improved after migration.

\section{Food, Health and other Social Entitlements of Migrant Labourers}

Internal migration spurred primarily by employment and marriage which shapes the economic, social and political life of India's sending and receiving regions. Regardless of the duration of their stay, migrant labors face myriad challenges at their destinations because of diversified cultures and traditions. Among the challenges, restricted access to basic needs such as identity documentation, social entitlements, housing and financial services. The construction workers who are settled at the place of residence permanently from more than 10 years in renovated slum areas and Gulbarga colonies have permanent address and so have access to food security since they hold the ration cards through which they can buy food items at subsidized rates and under Anna Bhagya Yojana they are entitled for free rice .But the labourers who have migrated recently do not possess ration cards because they don't have a permanent address. Most of the times these workers buy provision at retail price which is burdensome. The cost of living is very high in metropolitan cities and 60-80 percent of workers spend a lot of earnings to buy food items. So they cannot have nutritious food with the limited income they earn. Moreover, these people possess ration cards and Yashaswini cards at their place of birth which is used by their families there. So, they usually buy rice from PDS shops when they go back home on visit, and purchase all other food items in Bangalore. Many of them stated that they cannot afford to buy vegetables and fruits other than onions and tomatoes.

The migrant workers often suffer from various ailments. They are denied health benefits at government hospitals since they don't have BPL cards. So they visit private doctors and spend about $300-400$ in a month for the treatment of normal ailments. Because of the dirty surrounding and water, they are prone to illness frequently. The health benefits that any citizen of the country is entitled to be denied to these workers only because of the reason that they have travelled away from their place of birth in search of livelihood. Many of the migrated workers from Raichur and Gulbarga do not send their children to schools because they do not have a permanent housing facility. They are often made to live in working sites till the work gets over, after their work is done they go in search of other work sites where they find employment opportunity.

The workers stay in small sheds, either on the construction sites/ basement or on neighboring vacant sides or roadside, tents made of plastic sheets and do not have ventilation. Among 100 respondents many of them worked for small contractors had to stay in vacant sites around work place , 87 respondents said that there was no electricity and had to manage with the street lights. Among them those working for apartments had sanitation and bathroom facility but those working for houses were not provided with bathroom facility. The workers who stay on construction sites get water that is used for construction purpose or had to borrow it from neighboring houses. Lack of safety, proneness to pests, mosquitoes, and rats are common. Most of these workers cook their food in the temporary sheds or outside the sheds.

\section{Working Conditions of the Migrant Labourers}

The lack of opportunities in less developed areas is drawing thousands of people from rural and semirural areas to migrate towards the big cities like Bangalore. As a burgeoning industry, the construction sector offers work. With limited skills and little or no formal education, migrant construction workers face a lot of problems in their work areas.

The majority of the migrant workers are illiterate and unskilled which makes them vulnerable to being exploited by the sub-contractors/contractors. They do not possess bargaining power and cannot claim their part of rights. The wages paid to them is lesser than the minimum wages fixed by the labour commission and many a times they are made to work more than eight hours without making payments for overtime. Compared to other states like Gujarat the minimum wages fixed by government seems to be lower. The workers take only $50 \%$ of the wages and keep the remaining with sub-contractors because they cannot keep it safely in their sheds. 
Only 15 percent of the migrant workers have bank accounts. Among them, many of them have it in their native place in the name of one of the family members. Only a small percent of around $2-5 \%$ of workers have a bank account in their own names in Bangalore. The workers lack the knowledge on how to open bank account and the lack of identification and address proof documentation are the reasons for not holding bank account in Bangalore. The Pan card is the mandatory document to open an account now which is avoiding many workers form opening an account. These workers send their money to their dependents through relatives, friends and mainly bus drivers who collect commission for doing the same.

Many of the construction workers are not provided with safety helmets and spectacles while welding, cutting stones especially those working in metro stations. Workers are prone to small accidents which leads to infection. We have a glaring example of nearly 22 construction workers who lost their lives while constructing Vikas Soudha in the year 200304.

Many of the empirical studies have also reported of some of the permanent ailments of workers working in metro stations and few have lost their lives. Small accidents are very common, and very sadly these workers are not covered under insurance.

\section{Suggestions}

- Awareness should be created among these workers regarding the health camps, nutrition and food intake and about the immunization campaigns.

- Creation of crèche facility at the work sites, compulsory schooling for the children till the age of 15 should be addressed seriously.

- $\quad$ Financial literacy to open bank accounts, keep money safe in their account is a must.

- Awareness about the existing labour laws for their protection, legal counseling, linkages with formal organizations and trade unions, placement cell etc. should be provided.

- $\quad$ Provision for enhancing skill base and skill acquisitions to workers which could bring more wages to workers.

\section{Conclusion}

The contribution of migrant workers to the economic growth of any country is immense but is hardly identified. The rural migration is mainly because of poverty, poor living conditions at their place of birth. They migrate for better living conditions and opportunities. They are kept out of the purview of welfare measures and legal services. Migrant construction workers should be ensured safe and secure working conditions. Their food, health, political security should be given the top most priority.

\section{References}

Abbas Rameez and Varma Divya "Internal Labour Migration in India Raises Integration Challenges for Migrants" - March 2014.

Dwivedi Ritesh. Dr. "Migration: An Overview and Relevant Issues" SMS, Vol- VIII, No.2, December 2012.

Jaysawal Neelmani \& Saha Sudenshna "The men behind the Metro - The Voiceless and Faceless Lot: Some Reflections of Metro Construction Workers in Bangalore" - International Journal of Humanities Social Sciences and Education, Vol 1, Issue 6, pp 49-55, June 2014.

Kamlesh Kr.Shukla, Sanjay Mishra, S.Tripathi \& Ashmin Singh "Urbanization and Migration Trends in India” Demography India, vol. 39, No.1 pp. 43-54, 2010.

Kumar Yogesh \& Ajay Anamika., "Linking separate worlds: Understanding the process of Rural - urban seasonal migration in India" Urban India, vol. 34, no. 1, 2014.

Muniraju.M .Dr. "Social and Working Conditions of Construction Workers in Bengaluru: An Empirical Study" Pezzottaite Journals, vol. 4, no. 1, 2015.

Pattenden Jonathan, "Migrating between Rural Raichur and Boomtown Bangalore: Class Relations and the Circulation of Labour in South India" University of East Anglia.

Rajashekar D \& Suchitra J Y "Employment Security for the Unorganized Sector Workers in Karnataka" - Working Paper 169, ISEC Bangalore 2006. 
Report of Karnataka State Construction Workers Zeitlyn Benjamin \& Deshingkar Priya "Internal and Central Union

Thapa Rukmini, Satyam Kumar Yadav "Rural Labour Migration in India: Magnitude and Characteristics" - International Journal of Applied Research, 1(2), pp. 114-118, 2015.

Weeks J.R., "Population: An Introduction to Concepts and Issues." Wadsworth, 2002.

Woodruff Gertrude M, "Family Migration into Regional Migration for Construction Work: A Research Agenda" - Working Paper 14, May 2014.

"Impact of Labour Migration to the Construction Sector on Poverty: Evidence from India" Policy Brief 13.

"Migrants \& Cities: New partnerships to manage mobility" -World Migration Report, 2015. Bangalore" The Economic Weekly Annual, 1960.

\section{Author Details}

Mrs.B.Shamala, Research Scholar, Department of Economics, Bangalore University, Bangalore, Karnataka, India

Dr.T.Rajendra Prasad, Professor and Chairman, Department of Economics, Bangalore University, Bangalore, Karnataka, India

Email ID:trprasadbub@gmail.com 